\title{
Corrigendum to "Development and Characterization of an Electroless Plated Silver/Cysteine Sensor Platform for the Electrochemical Determination of Aflatoxin $B_{1}$ "
}

\author{
Alex Paul Wacoo $\mathbb{D},{ }^{1,2}$ Mathew Ocheng $\mathbb{D}^{3},{ }^{3}$ Deborah Wendiro $\mathbb{D},{ }^{1}$ Peter California Vuzi $\mathbb{D},^{2}$ \\ and Joseph F. Hawumba $\mathbb{D}^{2}$ \\ ${ }^{1}$ Microbiology and Biotechnology Centre, Department of Product Development, Uganda Industrial Research Institute, P.O. Box 7086, \\ Kampala, Uganda \\ ${ }^{2}$ Department of Biochemistry and Sports Science, School of Biological Sciences, College of Natural Sciences, Makerere University, \\ P.O. Box 7082, Kampala, Uganda \\ ${ }^{3}$ Instrumentation Unit, Technology Development Centre, Uganda Industrial Research Institute, P.O. Box 7086, Kampala, Uganda
}

Correspondence should be addressed to Joseph F. Hawumba; jhawumba@cns.mak.ac.ug

Received 25 November 2020; Accepted 25 November 2020; Published 21 December 2020

Copyright (c) 2020 Alex Paul Wacoo et al. This is an open access article distributed under the Creative Commons Attribution License, which permits unrestricted use, distribution, and reproduction in any medium, provided the original work is properly cited.

In the article titled "Development and Characterization of an Electroless Plated Silver/Cysteine Sensor Platform for the Electrochemical Determination of Aflatoxin $\mathrm{B}_{1}$ ” [1], antiAflatoxin $\mathrm{B}_{1}$-Peroxidase antibody produced in rabbit IgG fraction of antiserum (product number SAB4200829) (Sigma Aldrich, Saint Louis, MO, USA) was mistakenly used as a reagent instead of anti-aflatoxin $B_{1}$ antibody (product number A8679) (Sigma Aldrich, Saint Louis, MO, USA).

Also in the results, Section 3.2 Electrochemical immune detection of aflatoxin $B_{1}$ the reading was taken from positive potential which was due to impedance measurement. However, this paper is based on the electro-catalytic activity of horseradish peroxidase on the negative potential. In the method Section 2.3, therefore, entry $600 \mathrm{~nm}$ should be $-600 \mathrm{~nm}$. In the result section, the whole of Section 3.2 should be revised as follows:

\subsection{Performance of the Electrochemical Immunosensor}

In order to test the performance of the developed sensor platform for the analysis of aflatoxin $B_{1}$, the sensor platform served as a working electrode and a competitive immunosen- sing format (Figure 1; step 5) was performed both in the absence and presence of free aflatoxin $B_{1}$ (Section 2.3). The response of the sensor electrode was tested using different concentrations of aflatoxin $B_{1}\left(0-1 \mathrm{ngl}^{-1}\right)$ and differential staircase voltammetry (DSCV) [20] was used for monitoring the signal (Figure 5). Figure 5(a) shows that the DSCV currents increase with a decrease in aflatoxin $B_{1}$ concentrations, suggesting that the peak potential is inversely proportional to aflatoxin $B_{1}$ concentration. Since the rate of reaction was dependent on the catalytic activity of HRP, the higher the concentration of bound anti-aflatoxin $\mathrm{B}_{1}$ antibody-HRP the higher the rate of reaction [2]. Therefore, in the absence of aflatoxin in the solution, more anti-aflatoxin $\mathrm{B}_{1}$ antibodyHRP bind on the sensor and the current generated was very high. While at high aflatoxin concentration, low level of anti-aflatoxin $\mathrm{B}_{1}$ antibody-HRP was available to bind on the sensor, and the output current generated was low due to reduced catalytic activity from HRP.

In the Section 3.3, stability and selectivity of the immunosensor entries are $60 \mathrm{mV}$ of the $4160 \mathrm{mV}, 360 \mathrm{mV}$ of the $4160 \mathrm{mV}$, and $760 \mathrm{mV}$ of the $4160 \mathrm{mV}$ should be $10 \mathrm{mV}$ of the $716 \mathrm{mV}, 62 \mathrm{mV}$ of the $716 \mathrm{mV}$, and $130 \mathrm{mV}$ of the $716 \mathrm{mV}$, respectively. The correct figure is as follows: 


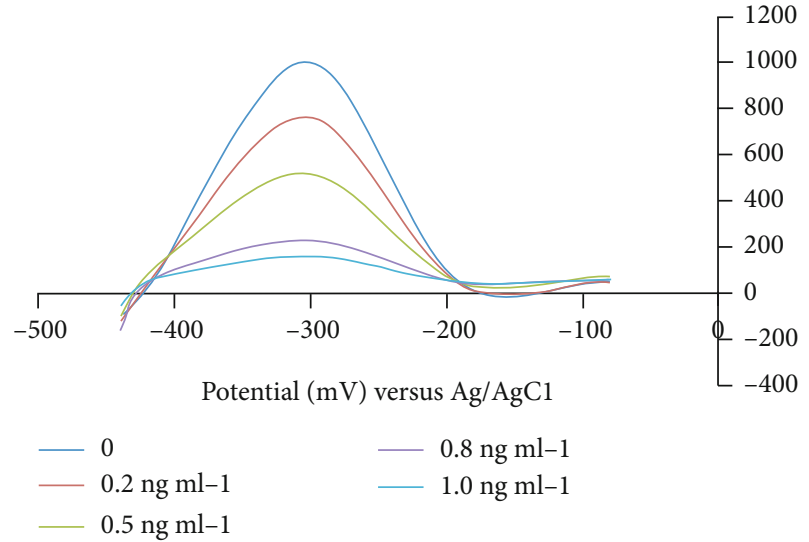

(a)

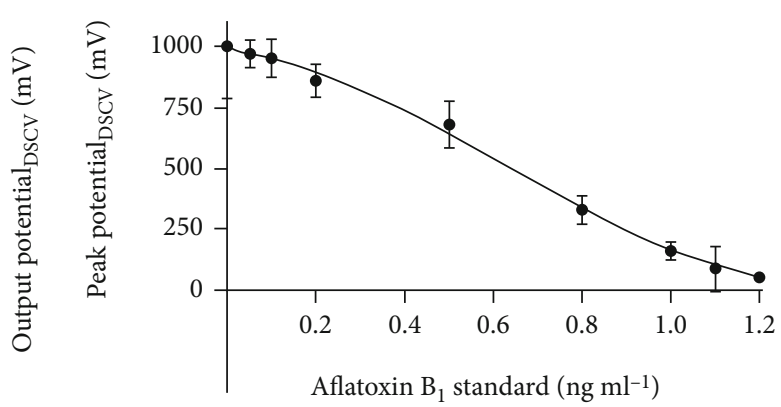

(b)

FIGURE 5: (a) DSCV response recorded for silver|cysteine|aflatoxin $B_{1} \mid$ HRP-blocked immunoelectrode for $0-1 \mathrm{ng} \mathrm{ml}^{-1}$ of aflatoxin $B_{1}$ concentrations in a pH 6.5 acetate buffer solution using $0.5 \mu \mathrm{g} \mathrm{ml}^{-1}$ of anti-aflatoxin $\mathrm{B}_{1}$ antibody-HRP (scan rate of $20 \mathrm{mV} / \mathrm{s}$ ). (b) A calibration curve of peak DSCV potential $(\mathrm{mV})$ versus aflatoxin $\mathrm{B}_{1}$ concentration $\left(\mathrm{ng} \mathrm{ml}{ }^{-1}\right)$.

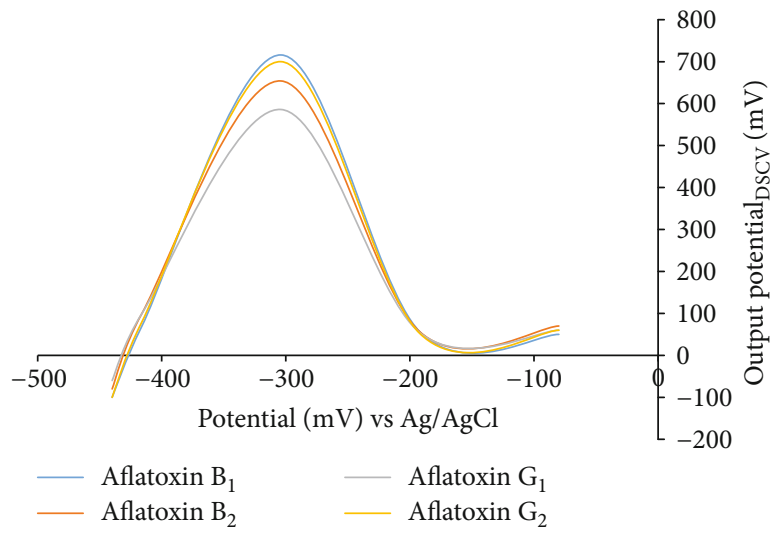

Figure 7: The specificity of the immunosensor platform toward aflatoxin $0.2 \mathrm{ng} \mathrm{ml}^{-1} \quad \mathrm{~B}_{1}, \quad 1.0 \mathrm{ng} \mathrm{ml}^{-1} \quad \mathrm{~B}_{2}, \quad 1.0 \mathrm{ng} \mathrm{ml}^{-1} \mathrm{G}_{1}$, and $1.0 \mathrm{ng} \mathrm{ml}^{-1} \mathrm{G}_{2}$.

Also, due to revision proposed for Section 3.2, Figure 6, Figure 7, and Figure 8 should be numbered as Figure 5, Figure 6, and Figure 7, respectively.

\section{References}

[1] P. A. Wacoo, M. Ocheng, D. Wendiro, P. C. Vuzi, and F. J. Hawumba, "Development and characterization of an electroless plated silver/cysteine sensor platform for the electrochemical determination of aflatoxin $\mathrm{B}_{1}$," Journal of Sensors, vol. 2016, Article ID 3053019, 8 pages, 2016.

[2] A. P. Danielson, D. van-Kuren, J. P. Bornstein et al., "Investigating the mechanism of horseradish peroxidase as a raft-initiase," Polymers, vol. 10, no. 7, p. 741, 2018. 